\title{
On Translation Obstacles of Metaphorical Language
}

\author{
Ke-yu $\mathrm{He}^{1}$ \& Hong Yun ${ }^{1}$ \\ ${ }^{1}$ School of Foreign Language, Sichuan University of Science \& Engineering, Zigong, Sichuan, China \\ Correspondence: Ke-yu He, School of Foreign Language, Sichuan University of Science \& Engineering, Zigong \\ 643000, Sichuan, China. E-mail: 470192133@qq.com
}

Received: October 8, 2017 Accepted: November 2, 2017 Online Published: November 24, 2017

doi:10.5539/ells.v7n4p104 URL: http://doi.org/10.5539/ells.v7n4p104

\begin{abstract}
Metaphor is not only an important figure of speech, but also a cognitive means of human mind. The people with different means of thinking have different cultures. The metaphorical language used by people must be fully saturated with culture peculiar to it. So because of the influence of cultural factor, the translation of metaphorical becomes the most important particular problem. Therefore, based on homogeneity and heterogeneity, the paper tries to explore the reasons for translation obstacles and strategy in order that his/her versions of metaphorical language could really become a medium in disseminating culture.
\end{abstract}

Keywords: metaphor translation, metaphorical language, culture, Homogeneity and Heterogeneity

\section{Metaphor and Translation}

\subsection{Definition of Metaphor}

What is metaphor? It seems to be a simple question and easy to answer it. But, in fact, up to now, no one can give a perfect and distinctive answer.

The word "metaphor" comes from the Greek word "metaphora". The root of "meta" means "across", and "pherein" means "carrying". The combined word refers to a particular linguistic process through which the characteristics of a certain object could be transferred to another, to the effect that the second object could be taken as the first one. (特伦斯·霍克斯, 1992, p. 1)

The Oxford Advanced Learner's English-Chinese Dictionary (4th edition) defines metaphor as (example of the) use of a word or phrase to indicate something different from (through related in some way to) the literal meaning as in "I"ll make him eat his words" or "she has a heart of stone". In Webster's Dictionary of the English Language Unabridged (Encyclopedic edition) metaphor is "a figure of speech in which one thing is likened to another, different thing by being spoken of as if it were that one: implied comparison, in which a word or phrase ordinary and primarily used of one thing applies to another (e.g., screaming headlines, all the world's stage;) distinguished from simile." Peter Newmark defines metaphor as:

"Any figurative expression: the transferred sense of a physical word; the personification of an abstraction, the application of a word or collocation to what it does not literally denote, i.e., to describe one thing in terms of another. [...] Metaphors may be "single"-viz, one-word-...or "extended" (a collocation, an idiom, a sentence, a proverb, an allegory, a complete imagination text." (2001, p. 104)

According to the contemporary views of metaphor, metaphor functions not only as a figure of speech, but also as a cognitive device, as Lakoff and Johnson say that the concept is metaphorically structured, and the activity is metaphorically structured. Therefore, the language is metaphorically structured. Metaphor is conceptual system to recognize new thing and understand an object thoroughly. From this view of point, we can say that metaphor has become an indispensable way to know the world. In this respect, it is of great significant to deal with the translation of metaphor. What is more, metaphor is culture-specific, which deepens the difficulty of metaphor translation. Therefore, it is quite necessary to achieve the task of the studies on the translation of metaphor from the angle of culture.

In the traditional point of view, metaphor is a figure of speech and a common language phenomenon, which is the same as others such as metonymy and synecdoche, etc. Metaphor is considered and studied at the word level as a figure of speech and its function of rhetoric is to decorate the discourse.

It is Aristotle who began to study metaphor in a serious way. In his Poetics and Rhetoric, he discussed 
metaphor's construction and rhetoric function. In the following 2000 years, what he has done greatly influenced on other rhetoricians' interpretation of this linguistic phenomenon. According to Aristotle, "Metaphor consists in giving the thing a name that belongs to something else; the transference is either from genus to species or from species to genus or from species to species or on the ground of analogy". (Ricoeur, 1976, p. 47) For its use, he thinks that metaphor is primarily ornamental. His followers later employed metaphor in ordinary language. They considered it as a special language, and deviant from literal usage.

In 1930s, Richard. A published the Philosophy of Rhetoric, and put forward the "Interaction theory". On the basis of it, Black developed and perfected the "Interaction Theory" Which quickly became the most powerful theory on metaphor since the time of Aristotle's "Comparison Theory" and Quintillian's "Substitution Theory". In the theory, Richard viewed that the purpose of studying metaphor is to understand this phenomenon by reflecting its phenomenon, operating mechanism and approach. He believed that every three sentences in oral communication are metaphorical, and metaphor is not only a linguistic phenomenon but also a way of human thinking. What is more, he also pointed out that the shortcoming of traditional metaphor is that it ignores the evidence that metaphor is essentially a communication among various thoughts and an interaction between contexts. From the above analysis of metaphor, we can find that the study on metaphor has gradually developed from linguistic domain to cognitive domain.

Almost at the same time, R. Jacobson, the famous American linguist, argues that metaphor originates in the interaction between a word and a sentence, or more precisely between language system and language process. He explains that metaphor is not only a structural phenomenon, but also a process. In the process of language, the meaning of a metaphor not only depends on its structural location in a sentence but also on the creative usage and interpretation of its users in the linguistic process. (Sudingfang, 1996)

Analyzing the above definitions, we can get several important points of the characteristics of metaphor. Firstly, the creation of metaphor is based upon the psychological activity of association of one thing with another one, and those forms might be similarity, resemblance or comparison, etc. It is not only a linguistic phenomenon but also a psychological process. "Metaphor is in fact based on a scientific observable procedure; the perception of a resemblance between phenomenon, i.e., object or processes." (Newmark, 2001, p. 104) Secondly, metaphor has been expanded from word into sentence, even a bigger structure such as a poem and a text. A word can be a metaphor; an idiom can be a metaphor; a sentence can be a metaphor; a poem can also be a metaphor, etc.

\subsection{Translation of Metaphor}

G. Lakoff and M. Johnson studied metaphor from a new perspective. In their collaborated book Metaphors we live by, metaphor is studied systematically in the light of cognitive semantics. Their argument is that human language is constructed in a metaphorical conceptual system; since our conceptual system plays a central role in defining our everyday realities metaphor also plays an important role in defining our everyday realities. Their argument is "that metaphor is pervasive in everyday life, not just in language but in thought and action," and "our ordinary conceptual system, in terms of which we think and act, is fundamentally metaphorical in nature." (Lakoff \& Johnson, 1980, p. 4) Furthermore, they point out that understanding is comparative to our cultural conceptual system done through conceptual system basing on culture. The definition given by them is that "the essence of metaphor is to understand and experience one thing in terms of another one."(Lakoff \& Johnson, 1980, p. 5)

Recently, metaphor research pays close attention to the influence of metaphor on social and cultural context, rather than only language and thought (Duffy, 2014). This is also a symbol of turning point of metaphor research. Metaphor has become an approach in the fields of implied linguistics, social science and humanities science (Cameron \& Maslen, 2010). In the following, the paper only focuses on the translation of conceptual metaphor as a smallest metaphorical language unit in terms of meaning, and never ignores social and cultural context.

Translating is a complex and fascinating task, as Richards (1953) once claimed that translating is probably the most complex type of event in the history of the cosmos. In the development of modern translation theories, there is a tendency that culture is introduced into this field. Translating becomes more complex for it has been defined as a cross-cultural communication event, and it involves not only two languages but also two cultures. This shift from emphasis on linguistic transfer towards emphasis on cultural transfer naturally exists in the translation of metaphor. Metaphor is not only an important figure of speech, but also a cognitive means of human mind. The people with different means of thinking have different cultures. The metaphorical language used by people must be fully saturated with culture peculiar to it. So because of the influence of cultural factor, the translation of metaphors becomes the most important particular problem. (Newmark, 2001, p. 104) This puts forward urgency for current studies on metaphor translation from the perspective of culture. 


\section{Homogeneity and Heterogeneity of Metaphorical Language}

\subsection{Reasons for Homogeneity and Heterogeneity of Metaphorical Language}

As for metaphorical heterogeneity, foreign scholars have not defined them exactly. However, they have conducted numerous researches on different languages. They studies demonstrate that there are both similarities and discrepancies between them. They reveal the existence of the similarities and the variances can be explained by embodiment philosophy and cultural differences. All these findings elaborate the nature of the homogeneity and the heterogeneity. As a matter of fact, the similarities are the homogeneity and the differences are the heterogeneity.

For language discrepancies, many scholars assert that cultural differences can explain this phenomenon. Humans live in the different areas. Different people have different assorted social history manifested in politics, economy, religion, legal system, cultural heritage, values and beliefs etc. all of these social lives build up basis for the culture-specific conceptualization of the world. According to anthropologists, cultural models based on the conceptualization of the world act a prominent role in human beings' thought and reasoning, so speakers' metaphor usage is constrained by these cultural understandings. Sharifian, Dirven, Yu, \& Niemeier (2008) have employed the position to emphasize cultural models as complex conceptual systems, which acts as building blocks of a "cultural group's cultural cognition". Language is a component of culture. Thus, cultural differences results in language variances. In the study by Kövecses (2003), the metaphor is not only cognitive but also culturally motivated. Lin (2002) thinks the conceptual metaphors are indicated in language and language in turn serves as a basic indicator of these conceptualizations.

Though the use of metaphor is universal in all cultures and languages, it seems that it carries the realities to be "culture specific". Lakoff \& Johnson (1980) affirm that metaphors not only mirror the conceptual system, but they shape the cultural models of a certain community.

Many scholars exemplify there are differences in cross-cultural metaphors. They illustrate differences existing between English and Chinese metaphor. Sun (2012, p. 45) states that metaphors show great discrepancies in western cultures and Chinese culture. Therefore, in terms of metaphors, western and Chinese people will interpret different metaphorical meanings. "Metaphorical Heterogeneity" means that "different metaphor users will construct different source domains for same target domains and different metaphor receptors will interpret different metaphorical meanings for same metaphors".

\subsection{Differences between English and Chinese}

As we see, different cultures hold different knowledge, experience and beliefs, etc. Intercultural translation becomes difficult and complex consequently for it has turned into a kind of transfer and communication of culture. At the same time, metaphor bears high contents of culture. Therefore, metaphor translation becomes especially difficult and tough. In order to achieve the equivalents of culture in metaphor translation it is necessary to construe the barriers in metaphor translation.

Due to cultural differences when a translator has to translate the text with metaphors from one culture into another it is certain that a number of problems can appear. Of course it is easy to find that metaphor holds the same image and the same implied and associative meaning both in target language and source language. This phenomenon is called cultural overlap. It explains the fact that cultural universals are defined as the modes of behavior common to all cultures. For example, pigs are universally associated with uncleanness and stench. Thus, if we translate English sentence He is a pig into Chinese in literal way, Chinese readers can understand it without any problem because the cultural implicative meaning of pig is similar in both cultures.

However, most of time metaphors in different cultures have different images, and the same images hold different cultural connotations that are indeed the root of making translation difficulty.

Animal metaphors differ greatly from culture to culture. For example, in Chinese "She is a cat" means that the girl is meek and gentle. But in English its meaning is that the girl is evil-minded as the cat is usually deemed as the symbol of jinx. Another one can take dog as example. Dog is treated in western countries as a lovely pet, and there are some metaphorical expressions such as "love me, love my dog", "dog like devotion" because dog is viewed as a lovable pet and a faithful friend. On the contrary, dog usually has the derogatory sense in Chinese culture like the expressions “狗仗人势” (be a bully under the protection of a powerful person), “狗嘴里吐不出 象牙” (a filthy mouth can't utter decent language), etc. In English we hold "he is as poor as a church mouse", but Chinese says “他穷得象叫花子”; English says “ fishing in the air”, but Chinese says “水底捞月”, and so on.

Therefore, another difficulty in metaphor translation comes from the reason that the English and Chinese 
metaphors hold the same semantic meaning, but have different cultural meanings. This also requires a suitable treatment to find suitable expression in target language.

Through the analysis it has been proved that metaphor translation is quite difficult and complex. There is a lot of misunderstanding appearing in the process of metaphor translation. Metaphor is quite different from literal language and its meaning is evasive and uncertain. What is more, metaphor is culture- specific, which deepens the difficulty of metaphor translation. So, it is quite necessary to achieve the task of the studies on the factors affecting the metaphor translation.

In a summary, language is the vehicle of culture and translation is the instrument for cultural exchange. Translation studies have been shifted from linguistic transfer to cultural transfer. As metaphor is fully saturated with the culture, it is of great significance for us to explore the cultural factors influencing on metaphor translation and then to seek for the appropriate principle in translating metaphor.

\section{Principles in Translating Metaphorical Language}

According to Nida, "Translation means translating meaning." (Liu, 1992, p. 41) Here meaning is a reference or a situation that a sign or a form represents. As what has analyzed above, it is clear that cultures which are embedded in languages are not absolutely incompatible, overlapping cultural elements constitute a basis for cross-cultural communication. (Li, 2001, p. 191)

From the perspective of modern semiotics, the essence of translation is to express the same thought and meaning in terms of two different languages. Therefore, the central task of translation is to reproduce thought and meaning in original text, rather than language sign in it. In another words, translation should do one's best to fulfill the equivalence between SL and TL to the largest extent. However, in the process of translation there must be some changes from SL text to TL text because of various linguistic and cultural elements.

Thus, the main principle in translating metaphors should be "seeking for the common ground and reserving the differences", namely, to not only faithfully transfer the information in the source metaphors, but also retain the characteristics of the source metaphors. There are grounds for the implementation of this principle. Firstly, the TL readers are conscious enough to accept different cultures and are sentimental about them because they are full of curiosity about the alien cultures. Secondly, alien expressions are brought into a language through its developing and communicating history.

There are many significant advantages of the application of the principle, which are listed in the following.

1) Enlarging the Cultural Vision of TL Readers

Many Chinese metaphors are vivid with rich images and may add new and special ideas to English. For example, “易如反掌” could be translated into “as easy as turning over one's hand (palm)”. The expression is lively and acceptable.

"Reserving the differences" means providing alien flavor to the TL readers. There are many metaphorical expressions in both English and Chinese. For example,

An unfortunate man would be drowned in a cup. 人一倒霉, 一杯茶也能淹死

A rolling stone gathers no moss. 滚石不生苔

armed to the teeth 武装到牙齿

a wolf in sheep's clothing 披着羊皮的狼

女大十八变 A girl changes several times before reaching womanhood

否极泰来 The extreme of adversity is the beginning of prosperity

丢面子, 保面子 lose one's face. save one's face.

出生牛犊不怕虎 A new-born calf makes little of the tiger

2) Furthering the TL Readers' Understanding of the SL Culture

As we know, there are few metaphors that are fully corresponding in English and Chinese, such as "all the rivers run into the sea; yet the sea is not full” and “百川归海而海不盈”. Most of metaphors are partial corresponding or not corresponding at all. For TL readers, these metaphorical expressions could make contribution to the understanding of the SL culture. We can list some of them as follows:

a lion at home, a mouse abroad 在家如虎, 在外如鼠

As you make your bed, so you must lie on it 作茧自缚 
沧海一粟 a drop in the ocean

睡得象猪 sleep like a log

热锅上的蚂蚁 like a cat on hot bricks

无风不起浪 no smoke without fire

杀鸡取暖 kill goose that lays the golden eggs

For the above examples, the active Chinese readers may have a chance to compare the different images with similar expressions in Chinese, thus bettering their understanding of the SL culture.

3) Enriching the Target language

Some foreign languages are so vivid and lively that they easily accepted by the TL readers. Thus, they gradually became a part of the target language. There are some English metaphorical expressions, which have often been used in Chinese as follows:

$\begin{array}{ll}\text { 白色恐怖 white terror } & \text { 蓝图 blue print } \\ \text { 第一手资料 first-hand material } & \text { 蜜月 honeymoon } \\ \text { 连锁反应 chain reaction } & \text { 君子协定 gentleman's agreement } \\ \text { 热线 hot line } & \text { 处女作 maiden works } \\ \text { 象牙塔 ivory tower } & \text { 洗脑 brain washing }\end{array}$

It is noted that different cultures have developed different ideology, values and attitudes, and it is possible for them to meet confrontations and conflict in communication. Therefore, we should make compromise on the basis of the mutual respect.

\section{Conclusion}

Finally, because metaphor is "illuminating some aspects of a topic, also obscuring other aspects." (Fan, 1992, p. 93) No matter how hard a translator works at metaphor translation, it is inevitable to lose some of colors from the source language. Metaphor translation can never be perfect. Besides, there are still some unsolved problems with the translation of metaphor due to the author's limited knowledge and ability. So, it is necessary to study further the translation of metaphorical language from the perspective of culture.

\section{Acknowledgment}

This research is supported by two projects: Scientific Research Fund Project of Sichuan Province, NO. SC16WY019, and Scientific Research Fund Project of Provincial Education Board of Sichuan, NO. ARC2016007.

\section{References}

Cameron, L., \& Maslen, R. (2010). Metaphor Analysis. London: Equinox.

Duffy. S. E. (2014). The Role of cultural artifacts in the interpretation of metaphorical expressions about time. Metaphor and Symbol, 29(2), 94-112. https://doi.org/10.1080/10926488.2014.889989

Fan, J. C. (1992). Appreciation and analysis of English Rhetoric (p. 93). Shanghai: Shanghai Jiaotong University Press.

Hawkcs, T. (1992). Gao Binzhong(Tr). On Metapho. Beijing: Kunlun Press.

Kövecses, Z. (2003). Language, figurative Thought, and Cross-cultural Comparison. Metaphor \& Symbol, 18, 311-320. https://doi.org/10.1207/S15327868MS1804_6

Lacoff, G., \& Mark, J. (1980). Metaphors we live by. Chicago: the University of Chicago Press.

Li, Y. X. (2001). Translation Strategy of Caption (7, p. 191). Beijing: Chinese Translators Journal.

Liu, D. (2002). Metaphor, Culture, and Worldview. The case of American English and the Chinese Language. Lanham: University Press of America.

Liu, M. Q. (1992). A Comparison and Translation of English and Translation. Nanchang: Jiangxi Education Press.

Newmark, P. (2001). A textbook of Translation. Shanghai: Shanghai Foreign Education Language Press.

Ortony, A. (1993). Metaphor and Thought (2nd ed.). Cambridge: Cambridge University Press. https://doi.org/10.1017/CBO9781139173865 
Richards, A. (1965). The Philosophy of Rhetoric. New York: Oxford University Press.

Sharifian, F., Dirven, R., Yu, N., \& Niemeier, S. (2008). Culture and Language: Looking for the Mind inside the Body. Berlin/New York: Moniton de Gruyter. https://doi.org/10.1515/9783110199109

Shu, D. F. (2000). Studies in Metaphor. Shanghai: Shanghai Foreign Language Education Press.

Sun, Y. L. (2012). On the Metaphor Differences of Ear Between English and Chinese (19, pp. 45-46). Data of Culture and Education.

Toury, G. (1980). In search of a Theory of Translation. Tel Aviv: Dorter Institute.

\section{Copyrights}

Copyright for this article is retained by the author, with first publication rights granted to the journal.

This is an open-access article distributed under the terms and conditions of the Creative Commons Attribution license (http://creativecommons.org/licenses/by/4.0/). 